\title{
"De letra de índios" \\ cultura escrita e memória indígena nas reduções guaranis do Paraguai*
}

\author{
“Indian writing" \\ written culture and Indian memory in the \\ Guarani reductions of Paraguay
}

EDUARDO NEWMAN

Doutorado em História Social pela UFRJ

Professor da Universidade Federal do Rio Grande do Sul Universidade Federal do Rio Grande do Sul, Instituto de Filosofia e Ciências Humanas, Departamento de História. Av. Bento Gonçalves, 9500 Porto Alegre, RS - Brasil eneumann@portoweb.com.br

RESUMO Nas reduções do Paraguai, a alfabetização praticada junto aos guaranis resultou em sociabilidades inéditas permitindo novos modos de relação com os outros e os poderes. Os usos e funções reservados a escrita facultou a determinados indígenas manusearem com desenvoltura o mundo dos papéis, prática acentuada a partir da segunda metade do século XVIII. Nessa época os índios letrados recorreram a escrita para estabelecer comunicação com seus companheiros ou produzir uma memória dos fatos considerados dignos de recordação. Por conhecerem o valor atribuído à escrita nas sociedades de Antigo regime eles procuraram em certas ocasiões estabelecer uma forma de registro de suas experiências e inquietações. Assim, os documentos "de letra de índios" constituem-se em um testemunho do quanto a cultura escrita e a memória estavam imbricados

* Artigo recebido em: 10/05/2009. Aprovado em: 01/06/2009. 
no cotidiano da população missioneira, em um jogo social através do qual procuravam salvaguardar uma versão indígena dos fatos transcorridos nas reduções do Paraguai.

Palavras-chave reduções guaranis, cultura escrita, história indígena

ABSTRACT In the Paraguayan reductions, the alphabetization of the Guarani Indians resulted in sociabilities unknown before, allowing new relationship models with the others and chains of power. The uses and functions reserved for writing allowed certain Indians to handle the world of papers with nimbleness, a practice that grew after the second half of the $17^{\text {th }}$ century. On that age, lettered Indians used writing as a way to communicate with their fellows or to produce a memory of the facts deemed worthy of remembrance. Because they knew the value attributed to writing in the Old Regime societies, on certain occasions they sought a way to register their testimonies and inquietudes. Thus, the documents "of Indian letters" constitute a testimony of how written culture and memory were intertwined in the quotidian of the population of the missions, in a social game through which they sought to safeguard an Indian version of the facts elapsed in the reductions of Paraguay.

Keywords Guarani missions, written culture, Indian histor

A Relação Abreviada, ${ }^{1}$ obra anônima, cuja autoria é atribuída ao marques do Pombal, foi publicada em Lisboa, no ano de 1757. No final deste livro figuram como anexos alguns "documentos authenticos" escritos por índios. Trata-se de três textos apreendidos em território missioneiro que, depois de traduzidos ao português, foram acrescidas de títulos fictícios com a finalidade de comprometer o trabalho executado pelos jesuítas. Através desse expediente, visava-se semear a dúvida e imputar aos padres a autoria dessas cartas.

Assim, como peça de defesa, foram redigidas várias Refutações à Relação Abreviada. ${ }^{2}$ Essas refutações são manuscritos elaborados por jesuítas

1 Relação abreviada da república que os religiosos das províncias de Portugal e Hespanha, estabelecerão nos Dominios Ultramarinos das duas monarchias. E da guerra, que neles tem movido, e sustentado contra os Exercitos Hespanholes, e Portuguezes; e por outros documentos authenticos. Lisboa: [s.n.], 1757. Há uma nova edição, creditada ao marquês do Pombal: MELO, Sebastião José de Carvalho e. República jesuítica ultramarina. Apresentação e transcrição, Júlio Quevedo Santos. Gravataí,/Porto Alegre/Santo Ângelo: ME/Martins Livreiro/Centro de Cultura Missioneira, 1989. Para uma aproximação ao impacto bibliográfico dessa obra no século XVIII, ver: CARDOZO, Efraim. Historiografia paraguaya: I - Paraguay indígena, español y jesuíta. México: Instituto Panamericano de Geografia e Historia, 1959, p.374-376.

2 A Relação Abreviada foi contestada à exaustão, ponto por ponto, por alguns jesuítas, principalmente em decorrência dos três papéis traduzidos. Segundo um dos religiosos estas Refutações constituíam-se na "única prueba de la 
que estavam em terras paraguaias, como Bernardo de Nusdorffer e Juan de Escandón. Os dois textos constituem-se em verdadeiros processos de defesa nos quais os religiosos dialogavam com o suposto libelista -no caso, Pombal- e apresentavam argumentos calcados no estudo das expressões lingüísticas, nas particularidades da língua guarani. Através desse expediente eles procuravam demonstrar que o "alboroto y emperramiento de los indios" que resultou na Guerra Guaranítica (1754-1756) -rebelião indígena deflagrada diante das clausulas estipuladas pelo Tratado de Madri- não fora estimulado pelos missionários da Companhia de Jesus, como alguns autores anti-jesuítas insistiam, mas sim uma atitude genuína dos guaranis.

Em meio à exposição de seus argumentos os missionários registraram informações sobre aspectos relacionados à prática "escriturária", reconhecendo a competência gráfica indígena. Somente em uma situação excepcional como esta, de crítica aguda ao trabalho evangelizador realizado na Província Jesuítica do Paraguai, explica o motivo pelo qual nestas circunstâncias, alguns religiosos decidiram se pronunciar sobre este assunto: a escrita dos guaranis.

Os dois jesuítas procuravam por meio de suas Refutações, esclarecer que: "Ahora pues este indio, que ciertamente sabia leer, y escribir (y aun contar) porque no podría el escribir este papel de Instrucciones?". ${ }^{3}$ Por certo, o reconhecimento da capacidade alfabética dos guaranis por parte dos padres missioneiros não era uma novidade, mas sempre esteve relacionada à produção de textos devocionais, a denominada reescritura cristã. ${ }^{4}$ Entretanto, nesse momento, a competência gráfica indígena foi reconhecida de maneira desvinculada da escrita religiosa.

Na Refutação elaborada por Escandón, ele se propunha a examinar os três papéis para desfazer as calúnias difundidas pelo "librito português". Argumentava que tão somente com este recurso, "se vera sin recurrir a otra prueba" a falsidade das acusações e, agregava, que bastava proceder à perícia caligráfica dos textos para se constatar que não havia "ni un solo ápice, o tilde, ni otra cosa alguna havia en ellos de mano ni de pluma de los P.P ni de Padre alguno sino que en todo, y por todos estavan todos tres escritos desde la Cruz a la flecha; y firma los que la tenian de letra de indios". 5

multitud de calumnias por el aqui recopiladas". Vide notas 3 e 5 a seguir.

3 Madrid. Archivo Histórico Nacional. (AHN) Clero-Jesuítas, legajo 120, caja 2, documento 75, f.24v. Suplemento de las censuras y licencias y del Prologo al curioso Lector, sin que salió â luz estos días la Relación abreviada de la republica de los P. P Jesuitas del Paraguay, yerros, y fe de erratas de la misma Relación, 1758 (c.a).

4 Refiro-me aos trabalhos de Nicolas Yapuguay que reescreveu em língua guarani os sermões que escutou nas missas. Uma breve biografia desse índio ilustrado pode ser consultada em: YAPUGUAY, Nicolás. Sermones y exemplos en lengua guaraní. Buenos Aires, Editorial Guarania, 1953, p.V-IX. (Edição fac-similar impressa na redução de San Francisco Xavier de 1727).

5 A.H.N. Clero-Jesuítas, legajo 120, caja 2, doc.74, f.54. Refutación de la Relación Abreviada de la República de los P. P Jesuitas impresa en Portugal, 1758 (c.a). 
Portanto, apesar das suspeitas quanto à sua autenticidade desses papéis, eles foram de fato escritos pelos guaranis e sem qualquer intermediação dos jesuítas, pois as mensagens expressam a tensão indígena vivida em função dos últimos acontecimentos. Dois destes papéis estavam assinados e pelos nomes e sobrenomes foi possível localizar nos arquivos outros documentos que comprovam a competência alfabética de seus autores. ${ }^{6}$

A conservação desses papéis escritos por índios é o resultado da preocupação das autoridades ibéricas em informar as suas respectivas monarquias da oposição indígena. Tais documentos são expressões de uma vontade de instaurar consenso sobre acontecimentos e que resultaram na produção de uma memória, ou seja, no registro dos fatos, o que explica a sua "sobrevivência". Os papéis indígenas eram a prova material de que dispunham os comissários demarcadores e mesmo os jesuítas, das manifestações autônomas de desobediência dos guaranis às ordens reais de mudança.

Nesse sentido, a escrita indígena e a polêmica sobre a autenticidade dos documentos de "letra de índios" são reveladores das disputas políticas que nos explicam, primeiro, a existência de textos como esses e, segundo, que foram tratados, à época, como material comprobatório da veracidade de argumentos políticos e, portanto, instauradores de uma versão dos acontecimentos.

Nas últimas décadas houve um interesse renovado por parte dos historiadores em relação aos textos escritos pelos ameríndios, papéis raros, preservados na forma de séries documentais, coleções ou mesmo algum texto manuscrito inédito, esquecido nos arquivos. A importância conferida a tais acervos, conjugados a uma nova perspectiva teórico-metodológica, ${ }^{7}$ tem contribuído para uma reavaliação geral das dinâmicas sócio-culturais estabelecidas na América colonial.

6 Sevilla. Arquivo Geral de Índias. (AGI) legajo 42, f.781-1146. Audiência de Buenos Aires, Correspondência con los gobernadores - años: 1728-1760. Anexos a correspondência de Joseph de Andonaegui, Buenos Aires, 8 de marzo de 1756. Das três cartas anexadas, uma é anônima e as outras duas apresentam ao final o nome dos responsáveis por sua redação, no caso Valentin Ybariguá e Primo Ybarenda, ambos integrantes do cabildo da redução de São Miguel. No final da correspondência enviada à península Ibérica consta um "Yndize de los Papeles que se le remiten al exmo Señor Don Francisco Julian de Arriaga" que está dividido em "Duplicados" e "Principales", onde estão relacionadas as transcrições ao espanhol das três cópias publicadas como apêndice documental na Relação Abreviada.

7 Para uma aproximação aos debates referentes a escrita e sociedade ver: BOUZA, Fernando. Del escribano a la biblioteca: la civilización escrita en la Alta Edad Média (siglos XV-XVII). Madrid: Síntesis, 1992; BOUZA, Fernando. Corre Manuscrito: una historia cultural del Siglo de Oro. Madrid: Marcial Pons, 2001; VIÑAO FRAGO, Antonio. Por una historia de la cultura escrita: observaciones y reflexiones. SIGNO, Revista de Historia de la Cultura Escrita. Universidad de Alcalá de Henares, n.3, p.41-68, 1996; PETRUCCI, Armando. Alfabetismo, escritura, sociedad. Prólogo de Roger Chartier y Jean Hébran. Barcelona: Gedisa, 1999; PETRUCCI, Armando. La ciencia de la escritura: primera lección de paleografia. Buenos Aires: Fondo de Cultura Económica, 2002; CASTILLO GÓMEZ, Antonio. (org.) Escribir y leer en el siglo de Cervantes. Barcelona: Gedisa, 1999; CASTILLO GÓMEZ, Antonio. (coord.) Historia de la cultura escrita. Del Próximo Oriente Antiguo a la sociedad informatizada. Gijón: TREA, 2000; CASTILLO GÓMEZ, Antonio. Entre la pluma y la pared: una historia social de la escrita en los Siglos de Oro. Madrid: Akal, 2006. 
Por sua vez, os documentos redigidos nas reduções - em guarani e espanhol -, sinalizam que em alguns episódios o apego a escrita - a escritofilia indígena - foi muito pronunciado. Assim, aqui não pretendo analisar a experiência missioneira unicamente a partir dos conteúdos presentes nesses textos escritos pelos guaranis, mas dimensionar os usos que essa sociedade reservou a sua capacidade gráfica e a quais demandas ela respondia. Enfim, demonstrar como a cultura escrita é reveladora dos valores e condutas de uma época.

\section{Escrita e elite indígena nas reduções}

As possibilidades inerentes à tecnologia da escrita logo foram percebidas por parte dos missionários, o que torna compreensível o interesse manifesto por parte das ordens religiosas em gramaticalizar os idiomas nativos existentes no Novo Mundo. Nos locais de presença jesuítica na América colonial foi evidente a preocupação de sistematizar as línguas indígenas. A Companhia de Jesus, através de seus religiosos, desde o século XVI, empreendeu a tarefa de gramaticalização (e de "dicionarização"), tarefa que materializou-se, por exemplo, em obras como a Arte de Gramática da língua mais usada na costa do Brasil, de José de Anchieta, publicada em Coimbra, em 1595; $;$ ou ainda, o trabalho semelhante de Antonio Ruiz de Montoya, no Paraguai, que elaborou o seu Arte y bocabulario de la lengua Guarani, publicado em Madri, no ano de 1639.9

Nas reduções ${ }^{10}$ administradas pelos jesuítas, o idioma guarani foi preservado devido à sua "redução gramatical", sendo esta a única língua falada e escrita nas missões, com características de língua semi-oficial. ${ }^{11} \mathrm{O}$ uso da língua guarani para a evangelização implicou na produção de uma enorme quantidade de textos e documentos nesse idioma. No início do século XVII, com a fundação das primeiras reduções administradas pelos jesuítas no Paraguai, logo começaram a funcionar os cabildos indígenas, uma modalidade de conselho, ou seja, um espaço privilegiado para o contato com a escrita. Tais locais foram uma adaptação dos cabildos espanhóis

8 ANCHIETA, José. Arte de Grammatica da Lingoa mais usada na costa do Brasil. Coimbra: Antonio de Mariz, 1595.

9 MONTOYA, Antonio Ruiz de. Arte y bocabulario de la lengua Guarani. Madrid: Juan Sanchez, 1640.

10 A palavra "redução" refere-se a reduzir, reconduzir a um local. Sem dúvida o princípio geral da redução foi o de congregar em povoados várias parcialidades indígenas. Quanto ao termo "redução", sua etimologia está relacionada à colonização hispânica e constitui-se na expressão da política global de catequese espanhola. Nas Leyes de Indias, há uma prescrição do que deveria ser a redução, porém na história da América espanhola existiram muitas variantes. Geralmente, os termos "reduções", "missões" ou "pueblos de índios" aparecem como sinônimos tanto nos documentos como na bibliografia sobre o tema. Nesse trabalho serão utilizados os termos "reduções" ou "missões" para designar as povoações de indígenas guaranis convertidos à cristandade pelos missionários a serviço da Companhia de Jesus na Província Jesuítica do Paraguai.

11 MELIA, Bartomeu. La lengua Guaraní del Paraguay: historia, sociedad y literatura. Madrid: MAPFRE, 1992; VILLAGRABATOUX, Sara Delicia. El Guarani Paraguayo de la oralidad a la lengua literaria. Asunción: Expolibro, 2002; ORUÉ, Pozzo. Oralidad y escritura en Paraguay: comunicación, antropologia e historia. Asunción: Arandurã/ Universidad Autónoma de Asunción, 2002. 
para acomodar a elite nativa e, assim, aproveitá-la no gerenciamento da população. ${ }^{12}$

Sem dúvida, o aprendizado da escrita foi uma das condições para o êxito da evangelização pretendida junto aos guaranis, e atuou como um fator para a definição de uma elite indígena, estabelecendo hierarquias sociais dentro do espaço reducional. O papel desempenhado por tal elite também pode ser mensurado através das funções administrativas existentes em cada redução e nos mecanismos de cooptação acionados pelos missionários. ${ }^{13}$ Afinal, cada redução contava apenas com um ou dois jesuítas para atender uma população que variava entre dois a três mil habitantes, ou mais. Sem a colaboração desses "índios principais", seria impossível a organização e o controle das atividades em geral. Certamente este grupo não se apresentava de maneira homogênea e tampouco todos os seus integrantes eram letrados. Enfim, houve por parte dos missionários um tratamento diferencial aos "indios de respecto y beneméritos", ou seja, os caciques e seus descendentes, aqueles indivíduos identificados como a elite indígena nas reduções.

As funções dessa elite ilustrada não estavam circunscritas apenas às questões administrativas, muito pelo contrário, abrangiam desde o gerenciamento material às manifestações religiosas e culturais de cada redução. Este grupo atuava como intermediário entre dois mundos culturalmente distintos. ${ }^{14} \mathrm{O}$ uso frequente da escrita habilitou a elite indígena nas reduções no manuseio do mundo dos papéis, como ocorreu de maneira acentuada a partir da segunda metade do século XVIII. Época na qual houve uma ampliação do uso social da escrita, quando esta deixou de ser um atributo exclusivo dos secretários, escreventes natos por excelência. Há inúmeros indícios de que a prática da escrita entre os guaranis missioneiros estava diretamente relacionada à condição sociocultural de alguns indivíduos, pois a instrução alfabética ministrada nas reduções foi seletiva. Porém, mesmo restrita a determinados grupos, ela atendia a diversas finalidades.

Motivo pelo qual a escrita indígena, registrada em diferentes suportes e com finalidades diversas, obriga-nos a rever em grande medida as avaliações simplistas que consideravam a atividade "escriturária" guarani nas reduções como um fato sem grande importância ou restrita ao trabalho dos índios copistas quando reproduziam textos canônicos. Os papéis escritos pelos guaranis missioneiros indicam que a necessidade social da escrita atingiu uma dimensão pronunciada no cotidiano das reduções, determi-

12 FURLONG, Guillermo. Misiones y sus pueblos de guaraníes. Buenos Aires: Imprenta Balmes, 1962, p.366-372.

13 Sobre a implantação das instituições político-administrativas nas reduções, ver: KERN, Arno A. Missões: uma utopia política. Porto Alegre: Mercado Aberto,1982, p.45

14 A respeito do papel dos caciques como "mediadores culturais" na América hispânica, ver: ARES QUEIJA, Berta \& GRUZINSKI, Serge. (orgs.) Entre dos mundos: fronteras culturales y agentes mediadores. Sevilla: Publicaciones de la EEHA, 1997; GRUZINSKI, S. O pensamento mestiço. São Paulo: Companhia das Letras, 2001. 
nando que a capacidade alfabética desfrutasse de prestígio e conferisse distinção aos índios letrados. ${ }^{15}$

Entre os integrantes dos cabildos missioneiros, todos conhecidos como "cabildoiguara" (cabildantes), há inúmeras manifestações de familiaridade no manejo da pluma. Por certo, o recurso a escrita conferiu uma nova lógica nas maneiras de conduzir os conflitos e de estabelecer recordações, relação evidenciada na presença da prática arquivística nas reduções. Em diversas oportunidades lançaram mão de informações históricas, que reportavam as Reais Cédulas recebidas dos monarcas de Espanha.

Portanto, mesmo de forma seletiva, foi facultado aos indígenas vias de acesso à instrução alfabética. Inicialmente como copistas e, posteriormente, como "autores" eles manifestaram um domínio pronunciado da "ars scribendi", que estava muito além do simples domínio do abecedário. Diante do convívio com os diferentes níveis da cultura escrita os guaranis letrados, em determinadas ocasiões, fizeram usos inesperados da alfabetização recebida, conferindo novas funções ao sistema gráfico.

\section{A Ars artificialiter scribendi nas Reduções}

A cópia de textos foi uma prática comum nas reduções, pelo menos até o final do século XVII. Época na qual a reprodução dos textos foi majoritariamente manuscrita. Através do trabalho especializado de certos guaranis, diversas obras foram reproduzidas anualmente e, algumas, com grande semelhança aos textos impressos. Nas reduções, havia entre a população indígena indivíduos que se especializaram no trabalho de copiar livros, imitando os caracteres impressos. A cópia manuscrita de livros era uma prática muito comum na Europa, sendo o trabalho realizado por várias mãos, denominado pecia. Essa prática chegou a ser bastante difundida nas reduções, sobretudo diante da capacidade demonstrada pelos guaranis para as reproduções a partir de cópias. Provavelmente essa atividade deve ter contribuído para aperfeiçoar o trabalho executado pelos guaranis missioneiros como, por exemplo, no momento de confeccionar os tipos para a impressão.

De fato, a importância da imprensa na difusão da cultura escrita era uma realidade perfeitamente conhecida pelos jesuítas. Motivo pelo qual a Companhia de Jesus, desde muito cedo, procurou assegurar a presença de algum "hermano coadjutor" para viabilizar a instalação de uma prensa tipográfica na Província jesuítica do Paraguai. Entretanto, somente no início do século XVIII, com a chegada de dois missioneiros a América, o padre

15 NEUMANN, Eduardo S. Práticas letradas guaranis: produção e usos da escrita indígena - séculos XVII e XVIII. UFRJ/IFCS, 2005. (Tese de doutorado) 
Juan Bautista Neumann, austríaco, e José Serrano, espanhol, é que a construção dessa máquina começou a ser viabilizada. ${ }^{16}$

Nessa época, o vice-rei do Peru atendeu ao pedido do padre Hernando de Aguilar, procurador-geral da Companhia de Jesus, e concedeu a licença necessária para que os jesuítas começassem a imprimir "en las misiones del Tucuman" livros em língua guarani. Em 1703, ele argumentava que

la Provincia de Tucuman tienen su religion muchas reducciones y Doctrinas Cuia numerosa Christiandad necesita para su mejor instrucción y enseñanza de que en su lengua materna, que es la Guarani se les ympriman los libros de la Doctrina y otros documentos especiales. ${ }^{17}$

É inegável que a "ars artificialiter scribendi" estava a serviço da evangelização. O livro mais antigo impresso nas reduções é de 1705. Trata-se de uma tradução ao idioma guarani, feita pelo padre Serrano, do tratado De la diferencia entre lo temporal y lo eterno, obra do padre Juan Eusébio Nieremberg. Esta obra apresenta uma série de gravuras, no caso reproduções feitas a partir do trabalho de Gaspar Bouttats, executadas por índios gravadores, sem deixar dúvidas quanto à qualidade e nitidez das páginas impressas, atestando o alto grau de refinamento que as artes gráficas atingiram junto aos guaranis. ${ }^{18}$ Apesar da ampla participação indígena na elaboração dessas obras, praticamente todas eram reproduções de trabaIhos de autores europeus.

Por certo, a execução dessas atividades permitiu manter as bibliotecas bem providas ${ }^{19}$ e os catálogos demonstram a existência de um número apreciável de volumes, obras em sua grande maioria religiosas. Durante as duas décadas de atividade dessa máquina foram impressos aproximadamente 23 livros nas reduções. ${ }^{20}$ Tudo indica que os resultados obtidos nas tarefas de impressão foram expressivos, e a participação da elite guarani nessas atividades foi decisiva. Ao que tudo indica às habilidades letradas de alguns indígenas foram canalizadas para tais atividades, tanto através da cópia de documentos, como nas tarefas de impressão.

16 FURLONG, Guillermo. Orígenes del arte tipográfico en América: especialmente en la República Argentina. Buenos Aires: Editorial Huarpes, 1946, p.140; FERNANDEZ, Stella Maris. La imprenta en Hispanoamérica. Madrid: Asociación Nacional de Bibliotecarios Archiveros y Arqueólogos, 1977, p.131.

17 Biblioteca Nacional do Rio de Janeiro. (BN/RJ) Coleção de Angelis, Manuscritos 508(22) Annuas. Documento número 530. Licencia acordada por el Virrey del Peru de Imprimir libros en lengua guarani, en las misiones del Tucuman, 1703.

18 Em sua maioria, eram textos com finalidade religiosa, como indica a consulta às obras impressas nas reduções: catecismos, sermonários, exemplos e vocabulários, tudo em guarani Essas lâminas podem ser visualizadas na reprodução realizada por um bibliófilo chileno; ver: MEDINA, José Toribio. Historia y bibliografia de la imprenta en el antiguo virreinato del Río de la Plata. La Plata: Taller de Publicaciones del Museo, 1892

19 Em 1747, o padre Bernardo de Nusdorffer, ao referir-se às bibliotecas missioneiras, mencionou "que en cada pueblo se hiciera un nuevo catálogo de libros que hay en todos los demás, por haberse añadido muchos" .FURLONG, Guillermo. Bibliotecas argentinas durante la dominación hispánica. Buenos Aires: Editorial Huarpes,1944, p.57.

20 PLA, Josefina. El barroco hispano-Guaraní. Asunción: Editorial del Centenario S.R.L, 1975. Ver apêndice 2: "Lista bibliográfica de Misiones", relação de todas obras impressas nas reduções. 
Em 1721, na redução de Loreto, foi impresso o Manual ad usum Patrum Societatis Jesu, com 266 páginas foliadas e 79 sem numerar. Um ano depois, em Santa Maria Maior, se publicou um espesso volume de 589 páginas, intitulado Vocabulario de la lengua guarani compuesto por el padre Antonio Ruiz de Montoya (...) Revisto e aumentado por otro religioso de la Compañia de Jesus. Esses dois livros são atribuídos a Pablo Restivo. Segundo Guillermo Furlong, trata-se das obras mais perfeitas, confeccionadas nas oficinas tipográficas das reduções, depois do livro de Serrano. ${ }^{21}$ O Manual ad usum Patrum, cuja autoria inegável é de Restivo, contou com a colaboração de uma equipe de tradutores e consultores nativos, em especial no que diz respeito à língua guarani, de que Restivo nunca prescindiu em suas obras. Esse livro ficou conhecido como Manual de Loreto, e segundo o estudo exaustivo de Palomera Serreinat, o objetivo de sua elaboração foi o de reunir em uma única obra os textos guaranis próprios as ações litúrgicas, evitando o incômodo de manusear simultaneamente dois ou três livros. ${ }^{22}$ Este manual é bilíngüe, tendo sido impresso em guarani e latim, sem apresentar nenhuma palavra em espanhol. A participação indígena nessas tarefas estimulou, provavelmente, os guaranis envolvidos na sua confecção a elaborarem eles mesmos os seus livros.

Uma referência obrigatória quanto à aptidão indígena para as letras são as obras elaboradas por Nicolas Yapuguay, cacique e músico da redução de Santa Maria Maior. Por sua condição de índio ilustrado, ele redigiu e publicou, em 1724, a sua Explicación de el catecismo en lengua guarani. Três anos depois, na redução de São Francisco Xavier, foi impresa a obra Sermones y exemplos. ${ }^{23}$ Através dessas recriações, Yapuguay deixou testemunhos do seu excelente domínio da cultura letrada, vertendo para a língua guarani categorias da cristandade. Contudo, sua atividade era supervisionada, restringindo-se a conteúdos cristãos. Enfim, havia uma vigilância sob o que se escrevia e imprimia.

Apesar do controle exercido sob a escrita, a produção textual de Yapuguay suscitou algumas polêmicas quanto à autonomia escriturária dos guaranis. ${ }^{24}$ Sem dúvida estas duas obras são uma prova da capacidade intelectual indígena, demonstrando como os guaranis não estavam limitados apenas a imitação de cópias. Apesar das evidências inequívocas da criatividade indígena, as informações provenientes dos jesuítas, em geral,

21 FURLONG, Guillermo. Orígenes del arte tipográfico en América. p.144.

22 SERREINAT, Lluis Palomera. Un ritual bilingüe en las reducciones del Paraguay: el Manual de Loreto (1721). Roma: Pontificium Athenaeum S. Anselmi de Urbe, Pontificium Institutum Liturgicum, 2001, p.222. (Thesis ad Lauren, n.283).

23 YAPUGUAY, Nicolas. Sermones y exemplos en lengua guaraní.

24 Esse tema foi explorado por Guillermo Furlong, que após tecer algumas considerações sobre os critérios de originalidade e estilo afirmou: "hemos de decir que no hubo, que sepamos, escritor alguno entre los indígenas de las Misiones", para logo a seguir acrescentar que "si por escritores entendemos a los hombres de cultura superior, que tuvieron la capacidad de expresar también en forma más o menos original, es indiscutible que hubo en las Reducciones escritores". FURLONG, Guillermo. Misiones y sus pueblos, p.593. 
apenas enfatizavam a destreza dos guaranis na reprodução de modelos, ${ }^{25}$ especialmente na execução de trabalhos manuais, sem referir jamais às potencialidades "inventivas".

Se, por um lado, as obras impressas estavam sob uma estrita vigilância, por outro os textos manuscritos apresentavam maiores oportunidades de autonomia, de liberdade criativa. Através da crônica de José Manuel Peramás, jesuíta missionário no Paraguai, somos informados, por exemplo, que os guaranis, além de serem ávidos leitores, também "ellos mismos eran escritores". Inclusive, ele afirmou ter conhecido dois indígenas, "autores de libros no religiosos" fato que demonstra o quanto a capacidade de escrever estava bastante disseminada entre os índios missioneiros, permitindo-Ihes produzir forma textuais inusitados ${ }^{26}$

Ao que parece, o custo elevado do papel foi uma das prováveis causas da suspensão das atividades tipográficas nas reduções. Por razões materiais, a escrita também foi praticada em couro. Nesse material foram confeccionados inclusive pequenos catecismos e livros. Portanto, o que poderia variar era o material no qual os guaranis estavam escrevendo, como indicam as mensagens em papel, cruzes de madeira e mesmo avisos em pedaços de couro.

\section{Rebelião indígena e comunicação escrita nas Reduções}

O debate sobre a história das reduções esteve durante muito tempo condicionado por uma concepção de que os índios catequizados não produziram, durante a sua vida em redução, registros escritos. Fato que os impossibilitava de expressarem, portanto, o seu ponto de vista quanto à experiência reducional. Nesse sentido, o relato lavrado pelos jesuítas seria, assim, o único testemunho dessa experiência. Entretanto esta avaliação deve ser contraposta ao fato de que os guaranis aprenderam a escrever.

Como vimos, os missionários ao executarem seus trabalhos de evangelização valorizaram o ensino das "artes y ofícios" aos seus tutelados, habilitando-os, dessa forma, em várias tarefas, como a de copiar e, até mesmo, de escrever documentos. E, mesmo diante do controle exercido pelos jesuítas, ${ }^{27}$ os guarani missioneiros, em determinadas ocasiões, utilizaram

25 Segundo o padre Aguilar os guaranis, "fueron excelentes 'copistas-escultores' e 'copistas-pintores' (...) pero faltos de toda creatividad y también de una adecuación espontánea". SUSNIK, Branislava. Los aborígenes del Paraguai, II: Etnohistoria de los Guaraníes: época colonial. Asunción: Museo Etnográfico Andrés Barbedo, 19791980, p.255.

26 Através da obra de Perámas somos informados da existência de uma "historiografia indígena missioneira". Ao comentar sobre livros escritos por guaranis, ele mencionou que na redução de Corpus havia um índio chamado Melchor que escreveu uma obra de caráter histórico, também referiu-se a um outro que escreveu a História da redução de São Francisco Javier. PERAMÁS, José Manuel. La República de Platón y los Guaraníes. Traducción y notas de Juan Cortés del Pino. Prólogo de Guillermo Furlong. Buenos Aires: Emecé Editores, 1946, p.160.

27 "Si la alfabetización misionera alcanza posiblemente, en esta área, un mayor porcentaje de la población que en México (para no hablar de las áreas menos privilegiadas), el control misionero sobre la cultura literaria es mucho 
sua capacidade letrada de maneiras, muitas vezes, inesperadas. Assim, a escrita inserida em contextos mais amplos permite identificar a partir de suas materialidades os dispositivos presentes nos textos, identificando as distintas intenções que nortearam o ato de escrever e as relações com o poder.

Um período de intenso recurso a informação epistolar e de diversos usos do letramento por parte dos índios, sem o controle jesuítico, está relacionado ao início dos trabalhos de demarcação dos novos limites entre os domínios ibéricos na América meridional. Com efeito, o Tratado de Madrid celebrado em 1750 pelas monarquias ibéricas, desencadeou a "reação escrita" dos guaranis. Ao tomarem conhecimento do teor desse Tratado, eles reagiram de uma maneira previsível: insubordinaram-se contra as ordens de transmigração a que estavam sendo submetidos diante da sua condição de vassalos do rei de Espanha. Motivo pelo qual a batalha dos papéis precedeu o conflito armado nas reduções. Nesse período, a escrita foi praticada por outros sujeitos como os administradores e demais integrantes dos cabildos missioneiros que, em determinadas circunstâncias, tentaram atuar na defesa de seus interesses e da coletividade.

Inicialmente os índios procuraram esclarecer as autoridades encarregadas da demarcação, através de cartas escritas em guarani, os motivos pelos quais não entregariam as suas reduções aos portugueses. Assim, eles externaram o seu ponto de vista por escrito, procurando anular ou impedir a execução do referido Tratado. Apresentavam argumentos calcados nos inestimáveis trabalhos de guerra prestados ao rei de Espanha na defesa das fronteiras sul-americanas, defendendo as terras missioneiras, exatamente contra os inimigos lusitanos. Como as manifestações dirigidas às autoridades hispânicas não resultaram em nenhuma alteração na fixação dos novos limites, em 1754, eclodiu um conflito conhecido na historiografia como Guerra Guaranítica (1754/1756). Com o início dos trabalhos de demarcação houve o rompimento da aliança guarani-jesuítica, momento a partir do qual os índios destinaram a escrita uma finalidade política, utilizando-a como instrumento das práticas de seu auto-governo. Em síntese: por conta das experiências anteriores de contato com o mundo dos papéis os guaranis procuraram, em um momento de crise, negociar diretamente com os agentes da administração colonial, oportunidade na qual a prática da escrita foi muito frequente entre os índios rebelados. ${ }^{28}$

Nesse aspecto a habilidade gráfica tanto atendia as finalidades usuais, no caso o gerenciamento da vida em redução, como facultava oportu-

más estricto". LIENHARD, Martin. La voz y su huella: escritura y conflicto étnico-social en América latina (14921988). Lima: Horizonte, 1992, p.70 (3ª edición revista y aumentada).

28 NEUMANN, Eduardo S. Escribiendo en la frontera del Paraguay: prácticas de la escritura guaraní durante la demarcación de límites (siglo XVIII). Cultura Escrita \& Sociedad, n.7, p.159-190, 2008. 
nidades inusitadas para que os integrantes da elite expressassem suas opiniões. Duas perguntas decorrem desta constatação: O que os guaranis procuravam garantir através da cultura escrita? Por que a palavra escrita foi valorizada pelos índios durante os trabalhos de demarcação de limites?

Em primeiro lugar, para responder a essas indagações é necessário dimensionar a aquisição da escrita como um processo inserido nas estratégias evangélicas, visando a conversão dos guaranis. Tal processo gerou efeitos não esperados e desdobramentos que nos revelam aspectos inerentes a "colonização do imaginário" indígena. ${ }^{29}$

Por sua vez, o reconhecimento do valor histórico desses documentos indica que, a decisão conjunta das coroas Ibéricas deflagrou nos guaranis missioneiros a preocupação em torno dos cuidados com os procedimentos letrados. A decisão de manifestarem por escrito suas opiniões legou aos historiadores documentos que permitem avaliar a elevada insatisfação e a mobilização desses indígenas explicitando, sobretudo, a importância que passou a ser atribuída à cultura escrita nessa sociedade.

Entretanto, de modo geral, tais documentos apenas foram explorados nos seus aspectos lingüísticos, sendo relegadas ás implicações históricas a um segundo plano. A profusão de textos produzidos pelos guaranis, em meados do século XVIII permite, portanto, indagar as relações existentes entre as práticas da escrita, memória e conflito nas reduções. Enfim as manifestações letradas inerentes a uma organização social inserida nas práticas culturais do Antigo regime.

Assim, uma das modificações deflagradas a partir da rebelião nas reduções refere-se ao fato de que à escrita deixou de ser uma prerrogativa exclusiva, ou restrita aos trabalhos dos secretários. Diversos guaranis letrados manifestaram qualidades semelhantes à dos escrivões, principalmente àqueles indígenas com passagem ou cargo nos cabildos missioneiros, ou seja, os indivíduos que foram preparados para exercer tais tarefas. É a partir do manejo da pluma, do uso da tinta e do papel, que esses guaranis letrados deixaram provas de sua participação na oposição ao trabalho dos demarcadores de limites. Através desses papéis diversos guaranis tem saído do anonimato, pois deixaram registrados seus nomes e sobrenomes nas cartas enviadas aos seus companheiros. Assim, as epístolas redigidas por estes indígenas alfabetizados são um dos testemunhos da oposição guarani as decisões tomadas de maneira unilateral por parte dos monarcas ibéricos.

Um conjunto de documentos indígenas bastante reveladores são as cartas apreendidas em outubro de 1754, logo após a Batalha do Daymal, confronto travado entre uma milícia missioneira e o exército a serviço de Es-

29 GRUZINSKI, Serge. La colonización del imaginário: sociedades indígenas y occidentalización en el México español: Siglos XVI-XVIII. México: Fondo de Cultura Económico, 1991. 
panha. Tais correspondências permitem comprovar tanto capacidade gráfica de um segmento da elite letrada missioneira como demonstra um dos usos que destinaram ao seu saber letrado. As cartas apreendidas com Rafael Paracatu, cacique na redução de Yapeyu, são na sua maioria respostas enviadas pelos mayordomos que estavam nas estâncias..$^{30} \mathrm{~A}$ competência alfabética dos administradores indígenas permitiu ao cacique Paracatu manter contato assíduo com eles e, assim, coordenar temporariamente a resistência missioneira em Yapeyu. Através dessa troca de correspondência, tomamos conhecimento do conteúdo de documentos singulares a respeito dos usos internos reservados à escrita pelos guaranis.

A redução de Yapeyu foi uma das mais convulsionadas, principalmente diante da presença do exército espanhol em suas terras. Procurando obstruir a marcha das tropas hispânicas por suas estâncias, o cacique Paracatu e os integrantes do cabildo recorreram à correspondência escrita para agilizar a comunicação e gerir ações conjuntas. Os papéis apreendidos com Paracatu sinalizam primeiro, a preocupação das lideranças em responder aos pleitos formulados por seus companheiros. E, em segundo, revela a rapidez em atender, no mesmo dia, aos pedidos e consultas realizadas. Tais cuidados visavam manter os indígenas informados a respeito da movimentação dos exércitos ibéricos, notícias que bem administradas poderiam ampliar as possibilidades de êxito da oposição missioneira.

Nos períodos de agitação os índios rebelados mantiveram-se informados através de mensagens escritas, comunicando seus companheiros a respeito da movimentação dos espanhóis na região. Como a estância de Yapeyu era muito extensa, os mayordomos foram constantemente contatados e instruídos, bem como forneciam informes freqüentes a Paracatu. Algumas dessas correspondências eram coletivas, e ao final constava a expressão "todos los mayordomos te escrivimos".

Por meio dessas mensagens somos informados da imediata resposta às consultas, provavelmente pelo caráter diligente que os guaranis sublevados atribuíam ao informe escrito. Algumas cartas, por exemplo, foram respondidas no mesmo dia em que chegavam aos destinatários. Através desse conjunto de correspondências indígenas foi possível constatar a urgência da escrita no período de conflito. Em determinados contatos os guaranis agregavam as suas missivas expressões solicitando que "invieis la respuesta a esta carta". Tais manifestações são indícios da importância atribuída à escrita nas negociações políticas dos índios letrados com os

30 Valladolid. Arquivo Geral de Simancas. (A.G.S) Secretaria de Estado, legajo 7425, f.145 y 146. Papeles apreendidos con Rafael Paracatu, cacique da redução de Yapeyu - tratam-se de 15 traduções (papeles) ao espanhol, anexas ao informe de Thomas Hilson ao Marquês de Valdelirios-, arroio do Daymal em 8 de outubro de 1754; A.H.N. Clero-Jesuítas, legajo 120, documento 54, fl.114. Relato de Escandón, 8 de novembro de 1755 (Cogieronse al Cacique Paracatu varios papeles y cartas escrita en su propia lengua. Y ante todas cosas mucha prudencia rubrico de propia mano el governador y luego las mandó traducir para saber lo que contenía). 
seus interlocutores, fossem eles companheiros de redução, demarcadores ou qualquer outra autoridade. Enfim, uma preocupação presente às estratégias de guerra.

As correspondências dos mayordomos têm permitido resgatá-los do anonimato, exatamente pelo fato deles terem deixado testemunhos escritos de suas opiniões, quando participaram ativamente nos bastidores do conflito, promovendo novos usos às suas competências gráficas. Outros exemplos da escritofilia guarani - o apego à escrita - são os textos dos secretários, corregedores e alcaides quando desempenhavam as funções de cabildantes em suas respectivas reduções. De fato, ao tomarem o texto epistolar como modelo, eles desenvolveram formas de expressão voltadas a registrar suas opiniões ou intervir no rumo dos acontecimentos.

As cartas, cujas mensagens estavam centradas principalmente na comunicação oficial, foram fundamentos para outras modalidades de textos voltados a registrar experiências de caráter pessoal, ou coletivo. Há inúmeras provas do quanto os índios sentiram-se atraídos pela idéia de produzir relatos ou deixar mensagens. Em determinadas oportunidades alguns guaranis letrados manifestaram uma relação mais privada com a escrita elaborando um testemunho, uma "memória indígena", dos momentos atípicos verificados durante os trabalhos de demarcação.

\section{Memória indígena e cultura escrita nas Reduções}

Com o início da Idade Moderna a escrita passou a desfrutar de uma nova condição, quando começou a ser considerada como um artifício capaz de superar a perenidade do tempo. Um recurso apto a registrar de maneira fiável os acontecimentos e, assim, estabelecer memória. Afinal, uma das finalidades da escrita é superar o esquecimento. Entretanto, sabemos que o acesso a memória coletiva somente é possível através da experiência individual.

Inúmeros autores já abordaram a importância dos jogos sociais nos atos de rememorar e esquecer, fatores essenciais para a constituição de uma identidade coletiva. ${ }^{31}$ Se, de um lado, isso se evidencia nos vestígios documentais de que dispomos para o trabalho de investigação histórica, por outro, cabe aqui pensar sobre a memória ${ }^{32}$ e o significado dado ao ato de rememorar, especificamente nas práticas da catequese. Foco fundamental da catequese jesuítica, a memória, constituída sob a forma de ordenamento

31 Para uma aproximação a estes argumentos ver: HALBWACHS, Maurice. A memória coletiva. São Paulo, Vértice, 1990; POLLAK, Michael. Memória, esquecimento, silêncio. Estudos Históricos, Rio de Janeiro, n.3, v.2, p.3-15, 1989; LE GOFF, Jaques. História e memória. Campinas: Editora da Unicamp, 1996.

32 No século XVIII, a "memória" é definida como a "faculdade d'alma na qual se conservam as espécies das cousas passadas e por meio da qual nos lembramos do que vimos ou ouvimos (...). A memória é a tesoureira e a guarda de tudo que se lê, vê e ouve". BLUTEAU, Raphael. Vocabulário Portuguez e Latino. Rio de Janeiro: UERJ, [s.d.], p. 414. (Edição original de 1717). 
cronológico, calcava-se nos atos rituais e litúrgicos, na encenação ritual combinada com a escrita e ordenada linearmente. Trata-se daquilo que entendemos como "narrativa histórica", que rompe com outras formas narrativas, como a mítica - identificada não exclusivamente com a narrativa indígena, posto que à cristandade também têm as suas narrativas míticas. Enfim, uma nova forma de ordenar acontecimentos e relatá-los se expressa dentre os índios, particularmente nos momentos de conflitos e disputas nas fronteiras americanas.

Conseqüentemente, a memória histórica, calcada nos registros escritos, procura estabelecer uma transcendência que permita ultrapassar os limites do grupo. O domínio da escrita parece sedimentar uma "memória histórica", que aproxima a "pedagogia jesuítica" daquilo que Halbwachs enuncia como a diferença entre "memória coletiva" e "memória histórica". ${ }^{33}$

Com efeito, os autores dedicados ao tema da memória remetem ao embate entre as recordações e seus protagonistas nos atos de rememorar e esquecer, ambas as situações concebidas como um jogo de forças. Os documentos consultados apresentam indícios de atitudes por parte dos guaranis que tentam instaurar uma memória coletiva e, por conseguinte, um elemento de unidade de um grupo frente aos outros. Segundo Jacques Le Goff, a memória coletiva é um elemento essencial para a identidade, seja individual ou coletiva, mas

não é somente uma conquista, é também um instrumento e um objeto de poder. São as sociedades cuja memória social é sobretudo oral ou que estão em vias de constituir uma memória coletiva escrita que melhor permitem compreender esta luta pela dominação da recordação e da tradição, esta manifestação da

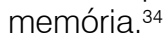

A prática da escrita havia introduzido entre os guaranis novas maneiras deles se relacionarem com o passado, visto que agora compartilhavam dos mesmos códigos dos colonizadores a partir de uma sociabilidade baseada na memória estabelecida através do "mundo do texto". De certo maneira, os autores são unânimes ao conceber que a memória, pensada a partir desses parâmetros, necessita de suportes físicos e espaços sociais para sua perpetuação. Nesse contexto, é a escrita que fornece aos índios das reduções subsídios para atualizarem a existência de uma coletividade que rememora a si própria e, também, sua territorialidade.

Escrever é um ato carregado de significados simbólicos, que comporta o estabelecimento de uma memória das coisas, das idéias e das pessoas por

33 Para esse autor a memória coletiva se distingue da histórica em dois aspectos: "É uma corrente de pensamento contínuo, de uma continuidade que nada tem de artificial, já que retém do passado somente aquilo que ainda está vivo ou capaz de viver na consciência do grupo que a mantém. Por definição, ela não ultrapassa os limites deste grupo". HALBWACHS, Maurice. A memória coletiva, p.80-84.

34 LE GOFF, Jaques. História e memória. p.476. 
meio da transmissão dos conhecimentos. De fato, este foi um dos principais objetivos daqueles que escreviam nos séculos XVI e XVII. Portanto a escrita inicialmente estava à disposição dos jesuítas como recurso a serviço da configuração de uma memória que corroborava os valores da cristandade e que depois passou a expressar um ponto de vista indígena.

A partir da elaboração de catecismos, gramáticas e vocabulários em guarani pelos jesuítas foram estabelecidas as condições para a evangelização promovida nas reduções. Através desses instrumentos de catequese foi possível aos índios fixarem, através da "memória oralizada", as verdades cristãs. O convívio com um número considerável de textos religiosos, utilizados durante os atos litúrgicos, facilitava a tarefa de memorização. Dessa maneira a população missioneira tomava conhecimento do potencial da escrita, fato que Ihes permitia um novo modo de relação com as formas de recordação, agora não mais restritas unicamente a transmissão oralizada.

\section{Um "índio historiador": a narrativa de Chrisanto Nerenda}

Entre os papéis escritos pelos guaranis há uma expressiva produção de cartas oficiais, com eminente caráter político administrativo - em decorrência da eclosão do conflito nas reduções - e mesmo de comunicação pessoal. Diante dessa expressiva produção escrita, alguns indígenas aventuraram-se na redação de um texto com característica de um relato pessoal. Este foi o caso da narrativa elaborada pelo mayordomo (administrador) da redução de São Luís Gonzaga, Chrisanto Nerenda. ${ }^{35} \mathrm{O}$ texto corresponde ao momento de sua chegada ao fortim lusitano - acompanhado de meia centena de companheiros - nas margens do rio Jacuí, até o retorno à sua redução de origem. Depois de ser capturado pelos portugueses em Rio Pardo, ele passou alguns meses em cativeiro. Posteriormente foi libertado e regressou a São Luís onde decidiu escrever uma extensa relação, em língua guarani, narrando os episódios que havia presenciado.

Através dessa narrativa somos informados a respeito dos incidentes, das situações de extrema adversidade, além das ameaças e privações as quais Nerenda esteve sujeito. Durante aproximadamente dois meses, entre o início de maio até meados de julho de 1754, ele foi submetido a várias pressões e conheceu pessoalmente o plenipotenciário a serviço de Portugal para executar a demarcação dos novos limites, Gomes Freire de Andrada. Em mais de uma ocasião foi interrogado sobre o modus vivendi

35 A.H.N. Clero-Jesuítas, legajo 120, caja 2, doc 56. Relación de lo que succedio a 53 Indios del Uruguay, cuando acometieron por $2^{\circ}$ con otros muchos el fuerte de los Portugueses del Rio Pardo, escribio un Indio Luisista que fue uno de estos 53 llamado Chrisanto, de edad como de 40 años, Indio Capax y mayordomo del pueblo, traduxo lo un misionero de la Lengua Guarani en castellano, San Carlos y febrero 19 de 1755. 
dos jesuítas, sem jamais sucumbir às ameaças recebidas. Esse guarani letrado, de aproximadamente 40 anos, foi um dos 14 sobreviventes a que Freire concedeu liberdade, depois de sua prolongada permanência, na vila de Rio Grande.

Foi, justamente, o fato dos conteúdos da Relación de lo que sucedió a 53 Indios del Uruguay estarem de acordo com a ótica pretendida pelos jesuítas, ou seja, a defesa do modo de vida cristã, que determinou a tradução e conservação do texto à época. A tradução desse documento, cujo original ficou arquivado na redução de São Luís, de acordo com a anotação do próprio Bernardo Nusdorffer, foi concluída em fevereiro de 1755. ${ }^{36}$

Nesse contexto, a narrativa desse guarani letrado é um dos textos que melhor sintetizou o estranhamento indígena em relação ao mundo extrareducional, especialmente a conduta dos portugueses, considerados como seus inimigos históricos. Com efeito, quase sem exceções, a escrita pessoal é marcada pelas experiências, por vezes traumáticas, sobretudo relacionadas a contextos excepcionais, ameaças ou perseguições. Situações como estas rompiam com a rotina da vida em redução, atuando como estímulo à elaboração de um registro da sobrevivência do narrador.

Como ele desempenhava o cargo de administrador dos armazéns e estâncias de sua redução, tal atividade demandava elaborarem informes ou prestarem contas quanto ao estado dos bens comuns. E, o controle desses assuntos, requeria, obrigatoriamente, registros escritos. Assim, a partir do uso corrente da escrita, inicialmente limitado a uma finalidade contábil, foi possível a indivíduos experientes produzirem modelos textuais melhor elaborados, cujos manuscritos estão muito próximos de uma escrita de caráter pessoal, de uma memória social.

Sabemos que, em meados do século XVIII, o relato elaborado por ele chegou a atingir grande repercussão no âmbito missioneiro, a se julgar pelas informações históricas sobre a circulação do texto. Em 1758, o ex-provincial do Paraguai, Manuel Quirino, ao elaborar um manuscrito compilatório dos principais episódios relacionados ao Tratado de Madri, qualificou Nerenda como um "índio historiador". ${ }^{37}$ Tal apreciação decorre da narrativa minuciosa elaborada a respeito do período em que permaneceu prisioneiro. Ao que tudo indica, ele recorreu à escrita para registrar sua posição pessoal, no caso o estranhamento em relação ao modo de vida dos portugueses. Dessa forma, manifestava sua adesão a vida em redução - e não o tradi-

36 A.H.N, Clero-Jesuitas, legajo 120, caja 2, doc. 56. Relación de lo que succedio a 53 Indios del Uruguay (...), (Ao final da tradução, Nusdorffer teve o cuidado de informar: "El original de este papel en Lengua Guarani esta en el pueblo de S. Luis a donde lo remiti. S. Carlos y febrero 19 de 1755. Bernardo Nusdorffer").

37 Madrid. Real Academia de la Historia. (RAH) Sig 9/2279, 9-11-5-151, Mss. p.184v. Sobre el tratado con Portugal. P. Manuel Quirino, Córdoba 22 de octubre de 1758 (Quando Manuel Quirino teceu seu comentário sobre Nerenda disse que "el indio historiador (...) fue uno de los cincuenta y tres indios bien capaz de San Luis en una relación que escrivio vuelto a su Pueblo, en que a su modo les cuenta a sus paisanos todo el suceso"). 
cional repúdio aos trabalhos de transmigração, expresso em outros textos indígenas do mesmo período.

Por certo, o relato elaborado por esse administrador indígena desfrutou de alguma notoriedade, a se julgar pelas informações históricas sobre circulação de cópias. Uma reprodução desse texto foi localizada na redução de São Lourenço, quando José Joaquim Viana ocupou-a, em maio de 1757.38 Enfim, tal texto é um exemplo de como a escrita indígena cumpriu uma função importante e de destaque na transmissão e difusão de informações e notícias entre os guaranis missioneiros.

Entre os escritos pessoais, figuram textos que foram motivados pelo desejo de formular testemunhos e assim manifestar opiniões que poderiam atingir outras platéias. Provavelmente Nerenda escreveu motivado pela expectativa de ser lido por outros, pelo exercício do seu ofício, quando direcionou sua habilidade letrada para a elaboração de um texto com características de memória pessoal. A prática da escrita de maneira freqüente favoreceu o desenvolvimento de outras formas textuais, gerando documentos que funcionam como suportes para recordações, um recurso para auxiliar as lembranças. Contexto no qual atribuída à escrita a função de depositária das alteridades geradas diante de experiências singulares. Por seu conteúdo esta relação escrita por um indígena apresenta elementos que a aproximam de uma memória coletiva, pois é uma forma de escrita pessoal mais centrada no exterior.

De fato, a cultura escrita nas reduções atendia a propósitos variados. Entretanto, nessa época de conflitos, ela também poderia expressar, sem dúvida, uma preocupação com a longevidade dos acontecimentos. Assim, atuava como um remédio contra o esquecimento, um antídoto para minimizar a amnésia social. Em certo sentido, escrever havia assumido entre a elite letrada, a condição de um testemunho que imaginavam não seria superado facilmente.

A escrita pessoal, dentre outros textos produzidos nas reduções, permite afirmar que a memória social foi relevante no cotidiano missioneiro e nos rumos da vida em redução. Afinal os guaranis vivenciaram acontecimentos excepcionais, justificando o interesse por preservá-los, para não serem relegados ao esquecimento. Outros indígenas, por sua condição de lideranças, igualmente recorreram à escrita por acreditarem que através desse procedimento poderiam interferir no rumo dos acontecimentos.

Pelo exposto, compreendemos como o exercício regular da escrita favoreceu o desenvolvimento de outras formas textuais e, segundo Antonio

38 A.G.S. Secretaria de Estado, legajo 7410, f.22. Inbentario de todos los papeles, y documentos que han entrado en esta Secretaria de la Capitania General, tocante a las averiguaciones echas sobre los autores de la desobediencia de los Indios, asi de las practicadas por disposición del Exmo Señor Don Joseph de Andonaegui, como de los papeles que encontro en el Pueblo de San Lorenzo el Brigadier Don Joseph Juachin de Viana (...), 20 de mayo de 1757. 
Castillo, apesar de ainda insuficientemente conhecidas, elas funcionam "comme objets-mémorie, c'est-à-dire comme instruments du souvenir et outils permettant de formuler les identités personnelles et collectives, relève également du domaine de l'ecrit". ${ }^{39}$ De fato, entre os escritos pessoais, figuram textos que foram motivados pelo desejo de formular testemunhos e assim manifestar opiniões que poderiam atingir outras platéias. Sua narrativa denunciava os riscos da proximidade com a gente portuguesa motivo mais que suficiente para os jesuítas apoiarem e endossarem a sua divulgação entre os demais guaranis. Tal narrativa, além de formar um registro dessa experiência, servia de reforço à imagem negativa difundida pelos jesuítas sobre o comportamento dos portugueses.

Todos os indícios sugerem que Nerenda também escreveu motivado pela expectativa de ser lido por outros, quando direcionou a prática da escrita (adquirida no exercício do cargo de administrador) para a elaboração de relato com características de uma memória pessoal. Nas entrelinhas de sua narrativa ele deixa transparecer que, além da preocupação com a memória, fosse ela individual ou coletiva, havia uma motivação adicional, relacionada ao desejo de proporcionar lições e fazer da sua experiência um exemplo para os demais.

\section{A título de conclusão}

A familiaridade manifesta com os diferentes níveis das práticas letradas, mesmo restrita a uma elite, havia promovido sociabilidades inéditas, permitindo a população missioneira estabelecer novos modos de relação com os outros e os poderes. O certo é que nos momentos de crise, de tensão ou impasse nas reduções coincidiram com a prática da escrita pelos guaranis. Possivelmente, em situações excepcionais, como nos momentos de contatos com os portugueses foram quando os indígenas missioneiros sentiram a necessidade de colocar no papel suas inquietações, sempre que as circunstâncias permitiram e, assim, formar um testemunho de algumas efemérides.

Como vimos, a partir da ldade moderna, a escrita foi celebrada como a ferramenta mais eficiente para dar constância dos acontecimentos. Assim, a escrita pessoal era considerada como o melhor e mais confiável modo de registrar os episódios que marcaram a trajetória do seu autor, ou de seus parentes e amigos. Nesse aspecto o acesso à memória coletiva somente é passível através da experiência individual. A maioria dos autores de documentos pessoais, não estava expressando apenas o seu ponto de vista,

39 CASTLLO GÓMEZ, Antonio. Entre le public et le privé. Strategies de lécrit dans I'Espagne du Siécle d'Or. Annales, Historie, Sciences Sociales, n.56, vol 4-5, p.821, 2001. 
no caso individual, por certo, também registrava a perspectiva dos demais sujeitos de uma comunidade.

Enfim, em algumas oportunidades os guaranis escreveram para estabelecer comunicação com seus companheiros ou produzir uma memória daqueles fatos avaliados como dignos de recordação. Por conhecerem o valor atribuído à escrita nas sociedades de Antigo regime eles procuraram em certas ocasiões estabelecer uma forma de registro de suas experiências e inquietações. Portanto, os documentos "de letra de índios" constituem-se em uma prova cabal de que a cultura escrita e a memória estavam imbricadas no cotidiano da população missioneira, em um jogo social através do qual procuravam salvaguardar uma versão indígena dos fatos transcorridos nas reduções do Paraguai. 